\title{
Studi Kebutuhan Desain Berdasarkan Riset Konsumen pada Produk Tas Sekolah Siswa SMA dalam Rangka Menentukan Design Requirement and Objective (DR\&O)
}

\author{
Bagus Dwi Kurniawan dan Bambang Tristiyono \\ Departemen Desain Produk, Fakultas Arsitektur Desain dan Perencanaan, \\ Institiut Teknologi Sepuluh Nopember (ITS) \\ e-mail: gacombi@prodes.its.ac.id
}

\begin{abstract}
Abstrak - Bidang riset konsumen berkembang sebagai perluasan dari bidang riset pemasaran untuk memungkinkan para pemasar meramalkan bagaimana konsumen akan bereaksi terhadap pasar dan memahami alasan-alasan mereka dalam mengambil keputusan untuk membeli. Begitupun dalam pengembangan sebuah desain produk, hasil-hasil riset pasar dan riset konsumen digunakan untuk mendefinisikan kebutuhan desain pada kasus-kasus tertentu. Beberapa penelitian menunjukkan hubungan yang signifikan antara hasil riset perilaku konsumen terhadap market oportunity dan product planning suatu perusahaan atau pelaku industri. Penelitian ini bertujuan mendefinisikan kebutuhan dan peluang desain pada produk tas sekolah siswa SMA berdasarkan data hasil riset konsumen. Mengingat tas sekolah merupakan sarana yang mempermudah siswa untuk membawa barang bawaan mereka ke sekolah setiap hari. Di lihat dari intensitas persebaran konsumen, tas sekolah membuka peluang yang cukup besar bagi pelaku industri tas. Informasi yang dihimpun dari sebuah riset konsumen akan dijadikan sebagai acuan dalam merumuskan Design Requirement and Objectives (DR\&O) sebuah produk. DR\&O berisi semua persyaratan keselamatan, fungsi, ruang lingkup, teknologi, operasional, dan batasan desain untuk produk baru atau turunannya.
\end{abstract}

Kata Kunci-Kebutuhan Desain, Riset Konsumen, Tas Sekolah, Sekolah Menengah.

\section{PENDAHULUAN}

$\mathrm{D}$ ALAM strategi pengembangan dan pemasaran sebuah produk, pengetahuan akan situasi dan perilaku pasar menjadi sangat penting. Karena semua keputusan pemasaran didasarkan pada asumsi dan pengetahuan tentang perilaku konsumen [1]. Begitu pula dalam merancang sebuah desain produk. Secara historis, desain produk diartikan sebagai proses menciptakan diferensiasi fungsional, namun belakangan ini desain produk semakin dianggap sebagai alat strategis dalam menciptakan preferensi dan nilai bagi konsumen [2]. Bentuk dan desain suatu produk adalah salah satu parameter bagi keberhasilan pasarnya. Di sisi lain, beberapa penelitian menunjukkan hubungan yang signifikan antara hasil riset perilaku konsumen, seperti sikap, keputusan pembelian dan word of mouth terhadap desain sebuah produk [3].

Peluang desain sangat mungkin didapatkan dari identifikasi kebutuhan konsumen berdasarkan riset konsumen. Menurut American Marketing Association (AMA), riset konsumen adalah fungsi yang menghubungkan konsumen, pelanggan dan publik dengan pemasar melalui informasi-informasi yang digunakan untuk mengidentifikasi dan mendefinisikan peluang [4]. Informasi yang dihimpun dari sebuah riset konsumen dapat pula dijadikan sebagai acuan dalam merumuskan Design Requirement and Objectives (DR\&O). DR\&O berisi semua persyaratan keselamatan, fungsi, ruang lingkup, teknologi, operasional, dan batasan desain untuk produk baru atau turunannya. DR\&O juga mengacu dari desain sebelumnya yang dihasilkan dari manufaktur, sertifikasi, dan batasan lainnya [5].

Dalam dunia pendidikan di Indonesia, kebutuhan tas sekolah menjadi bagian tak terpisahkan dari seorang siswa. Bagi seorang siswa tas sekolah merupakan salah satu alat bantu dalam aktivitas carrying setiap hari [6]. Siswa membawa barang-barang mereka dengan tas ke sekolah setiap hari. Barang-barang tersebut termasuk buku pelajaran, makan siang, peralatan olahraga dan gadget elektronik yang lebih baru seperti tablet, laptop, dan lain-lain. Dari penelitian-penelitian sebelumnya, menyatakan bahwa salah satu masalah serius yang dihadapi anak-anak dan remaja generasi sekarang adalah tentang bagaimana mereka membawa barang-barang mereka ke sekolah yang aman bagi kesehatan [7]. Oleh sebab itu, penelitian ini akan mengkaji lebih lanjut tentang kebutuhan tas sekolah berdasarkan perilaku siswa sehari-hari.

Penelitian ini bertujuan untuk mengidentifikasi kebutuhan desain tas sekolah untuk siswa SMA, barang bawaan, perilaku serta aktivitas sehari-hari dalam menggunakan tas sekolah berdasarkan data-data yang diperoleh dari riset konsumen dan studi literatur. Hasil dari kompilasi data dan studi literatur kemudian dijadikan sebagai acuan dalam merumuskan DR\&O [8].

\section{KAJIAN TEORI}

Riset konsumen berkembang sebagai perluasan bidang riset pemasaran untuk memungkinkan para pemasar meramalkan bagaimana konsumen akan bereaksi di pasar dan memahami alasan-alasan mereka dalam mengambil keputusan untuk memilih sebuah produk. Proses riset konsumen itu meliputi:

1. Menentukan tujuan riset

2. Mengumpulkan dan mengevaluasi data sekunder

3. Merancang studi riset primer

4. Menghimpun data primer

5. Menganalisis data

6. Mempersiapkan hasil riset

Langkah pertama dalam proses riset konsumen adalah menentukan dengan teliti tujuan studi. Merupakan hal 
penting bagi seorang desainer dan peneliti untuk menyepakati dari awal maksud dan tujuan studi untuk menjamin agar rancangan riset itu tepat. Tujuan yang dipertimbangkan secara teliti membantu menemukan jenis dan mutu informasi yang dibutuhkan. Pada riset kualitatif maupun kuantitatif, laporan riset memuat juga kesimpulan singkat mengenai hasil-hasil riset. Isi laporan memuat uraian lengkap mengenai metodologi yang digunakan, untuk riset kuantitatif juga memuat berbagai table dan grafik untuk mendukung hasil riset. Pendekatan untuk tiap-tiap jenis riset berbeda tergantung sudut metode pengumpulan data, rancangan sampel, dan macam alat pengumpulan data yang digunakan [9].

Hasil riset konsumen kemudian dimasukkan dalam beberapa tahapan proses pengembangan desain. Pada penelitian ini, penulis menggunakan teori "The Double Diamond Design Process Model".

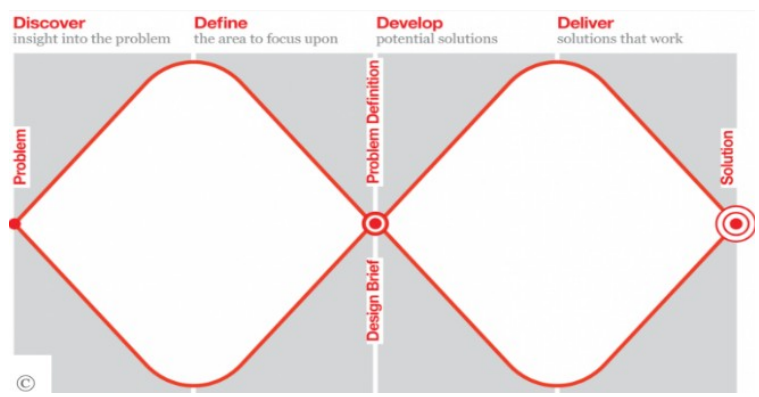

Gambar 1. "The Double Diamond Design Process Model"

(Sumber: A study of the design process, Design Council 2015)

Dibagi menjadi empat fase yang berbeda, yakni Discover, Define, Develop and Deliver, memetakan tahapan proses desain yang berbeda dan konvergen, menunjukkan berbagai mode pemikiran yang digunakan desainer. Tahapan awal dari proses pengembangan desain ini meliputi: market research, user research, managing informations, design research group.

Pada tahapan awal inilah, DR\&O dirumuskan dan ditetapkan sebagai dasar untuk menentukan product planning. Metode ini dikembangkan melalui penelitian internal di Design Council pada tahun 2005 sebagai cara sederhana untuk menggambarkan proses desain dan merumuskan kebutuhan desain [10].

\section{METODE}

\section{A. Studi Literatur}

Studi ini dilakukan untuk menganalisis data-data dari penelitian sebelumnya sebagai rujukan dalam menentukan kebutuhan desain pada tas sekolah. Rujukan tersebut meliputi data dan teori yang relevan mengenai riset konsumen, perilaku, identifikasi kebutuhan desain pada sebuah produk. Data sekunder didapatkan penulis melalui jurnal ilmiah, buku, artikel, dan literatur lainnya.

\section{B. Riset Konsumen}

Sumber pengumpulan data primer menggunakan teknik kuisioner. Selain itu penulis juga menggunakan metode observasi langsung untuk mengetahui perilaku responden dan eksisting produk di lapangan. Pengumpulan data dengan kuisioner dilakukan seacara online dimulai pada tanggal 20 November 2018 hingga 27 November 2018. Kuisioner ini disebarkan melalui beberapa platform diantaranya LINE, WhatsApp dan Facebook. Responden yang dituju adalah siswa tingkat Sekolah Menengah Atas dari beberapa SMA di Surabya. Susunan pertanyaan kuisioner yang disebarkan pada responden mengacu pada hasil studi data sekunder yang telah dilakukan sebelumnya dengan memerhatikan dan mempertimbangkan cakupan kebutuhan dan peluang desain. Sedangkan metode observasi dilakukan untuk mengetahui kondisi secara langsung baik aktivitas siswa maupun produk eksisting yang mereka gunakan. Pertanyaan pada kuisioner terbagi menjadi tiga bagian, yakni pertanyaan mengenai karakter responden, eksisting produk, dan trigger tentang kebutuhan dan peluang desain tas sekolah.

1. Karakter Responden

Pertanyaan yang diajukan seputar identitas responden meliputi nama, jenis kelamin, usia, asal sekolah, kelas, minat dan jurusan. Pertanyaan seputar identitas responden ini diajukan untuk mengetahui kelompok usia, teritori, dan jenjang kelas masing masing responden. Sehingga dapat dengan mudah dikelompokkan menjadi sebuah kelompok demografi. Karakter pengguna juga dapat dihimpun melalui pertanyaan pertanyaan minat dan jurusan sekolah.

\section{Produk Eksisting}

Pertanyaan seputar produk eksisting tas yang digunakan responden meliputi jenis tas, merek, spesifikasi, dan harga. Jawaban dari pertanyaan ini digunakan untuk mengetahui kondisi eksisting produk, trend, analisis kapasitas produk, dan spesifikasi dari produk yang ada di pasaran.

3. Kebutuhan dan Peluang Desain

Pertanyaan seputar kebutuhan dan peluang ini dituangkan secara tersirat tentang trend tas sekolah, desain, dan beberapa trigger lain seperti kebutuhan khusus atau keinginan mereka pada sebuah produk tas. Tujuan dari pertanyaan ini adalah sebagai gambaran sekilas tentang sejauh mana wawasan dan pengalaman responden selama menggunakan tas sekolah yang ada saat ini.

4. Aktivitas dan barang yang dibawa

Sedangkan pertanyaan seputar aktivitas diajukan untuk mengetahui perilaku keseharian siswa dalam menggunakan tas sekolah, baik saat jam sekolah maupun aktivitas di luar jam sekolah. Pertanyaan tersebut meliputi, kegiatan yang dilakukan di luar jam sekolah, barang yang dibawa ketika sekolah, dan barang-barang lain yang biasa mereka bawa dalam aktivitas sehari-hari.

\section{HASIL RISET DAN PEMBAHASAN}

Hasil dari penghimpunan data baik melalui observasi dan juga kuisioner online adalah sebagai berikut:

a) Data Observasi

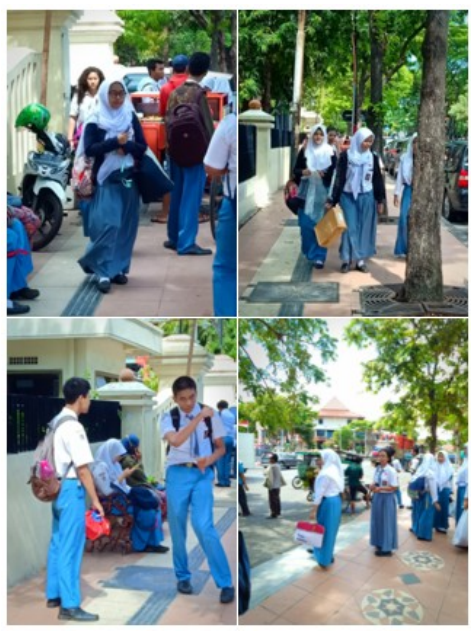

Gambar 2. Pengamatan di Lapangan. 
(Sumber: Dokumen Penulis)

Observasi dilakukan dengan mengamati situasi di lingkungan sekolah (SMA) pada saat jam berangkat dan pulang sekolah dari pukul 06.30-15.30 WIB. Pengamatan berlangsung secara continue dari hari pertama hingga terakhir dalam satu minggu.

Dari hasil pengamatan lapangan, dapat disimpulkan bahwa seluruh siswa pada umumnya menggunakan tas sekolah untuk membawa barang-barang mereka ke sekolah. Sebagian besar siswa bahkan membawa lebih dari satu tas untuk membawa keperluan lain seperti laptop, kotak makan, dan peralatan olah raga.

Gambar 2 adalah foto dokumentasi dari pengamatan di lapangan.

b) Kuisioner

Penyebaran data kuisioner memperoleh responden sebanyak 120 siswa yang secara keseluruhan adalah siswa Sekolah Menengah Atas dan sederajat. Sebanyak 109 responden adalah siswa SMA sedangkan 11 yang lain adalah siswa SMK. Sehingga data dari kedua jenis jenjang tersebut dapat digunakan dalam penelitian ini. Hasil dari penyebaran data kuisioner ini dijabarkan dalam empat jenis pertanyaan sesuai dengan metode yang telah dijelaskan sebelumnya.

Pembahasan pertanyaan seputar karakter responden adalah sebagai berikut:

\section{Jenis Kelamin}

Dari 120 responden yang pertanyaan tersebut, didapati 50 responden adalah laki-laki, dan 70 lainnya adalah perempuan.

Dari jawaban responden terhadap pertanyaan jenis kelamin di atas, dapat dilihat bahwa jumlah responden perempuan lebih banyak dibanding laki-laki. Dari hasil pengamatan pun juga demikian, jumlah siswi perempuan lebih dominan dibandingkan dengan siswa laki-laki. Data statistik Kemendikbud tahun ajaran 2016/2017 juga menyebutkan bahwa jumlah siswa SMA di Indonesia menurut jenis kelaminnya didominasi oleh peserta didik perempuan (Pusat Data dan Statistik Pendidikan dan Kebudayaan, 2016). Namun bukan berarti tas yang digunakan lebih dominan tas perempuan. Dari fakta di lapangan, sejumlah siswi perempuan cenderung menggunakan tas laki-laki. Ini terjadi karena kapasitas tas laki-laki lebih cocok digunakan untuk membawa barang bawaan ke sekolah yang cukup banyak. Sedangkan tas perempuan umumnya didesain sederhana dengan corak yang menonjolkan gaya feminin, seperti warna dan polanya.

2. Usia

Responden adalah siswa pada jenjang Sekolah Menengah Akhir dan sederajat. Artinya, responden adalah laki-laki atau perempuan dengan range usia antara 15-18 tahun.

\begin{tabular}{|c|c|c|}
\hline No & Usia & $\begin{array}{l}\text { Prosentas } \\
\mathrm{e}\end{array}$ \\
\hline 1. & 15 & $4 \%$ \\
\hline 2. & 16 & $26 \%$ \\
\hline 3. & 17 & $53 \%$ \\
\hline 4. & 18 & $17 \%$ \\
\hline
\end{tabular}

Dari data di atas dapat diketahui bahwa kelompok usia pelajar SMA adalah antara 15-18 tahun. Data serupa juga dapat dilihat dari jumlah siswa SMA Indonesia menurut kelompok usia yang di himpun oleh Pusat Data dan Statistik Pendidikan dan Kebudayaan 2016.

\section{Asal Sekolah}

Responden yang dituju adalah siswa tingkat Sekolah Menengah Atas dari beberapa SMA di Surabaya. Berikut adalah nama-nama sekolah beserta jumlah responden yang berpartisipasi dalam kuisioner yang telah dibagikan.

Tabel 2.

Daftar Sekolah yang berpartisipasi dalam kuesioner

\begin{tabular}{clc}
\hline \hline No. & Nama Sekolah & Jumlah \\
\hline 1. & SMAN 1 Surabaya & 44 \\
2. & SMAN 13 Surabaya & 31 \\
3. & SMA Muhamadiyah Surabaya & 34 \\
4. & SMKN 1 Surabaya & 11 \\
\hline \hline
\end{tabular}

Dari data di atas, dapat dilihat bahwa responden paling banyak adalah dari SMAN 1 Surabaya dengan jumlah responden 44 siswa. SMAN 1 Surabaya adalah salah satu SMA yang berada di pusat kota Surabaya. Selain SMAN 1, di wilayah yang sama terdapat beberapa SMA Negeri yang tergabung dalam satu area yang masyarakat sering menyebutnya dengan "SMA Komplek". Di area ini terdapat kurang lebih 5 SMA Negeri Surabaya. Dengan kata lain, tempat tersebut adalah wilayah dengan populasi siswa SMA terbanyak di Surabaya.

\section{Minat}

Minat di sini adalah pertanyaan yang diajukan kepada responden seputar kegemaran dan hobi mereka di luar pelajaran sekolah. Berikut jawaban responden terkait hal minat, kegemaran atau hobi:

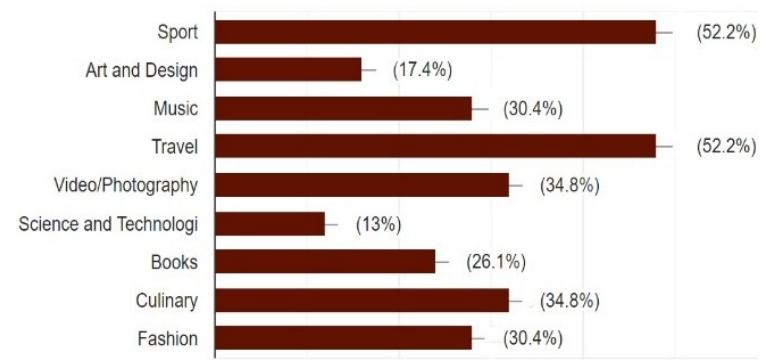

Gambar 3. Minat responden.

5. Jenis Tas yang Digunakan

Berikut adalah jenis tas yang digunakan oleh para responden untuk membawa barang bawaan mereka ke sekolah:

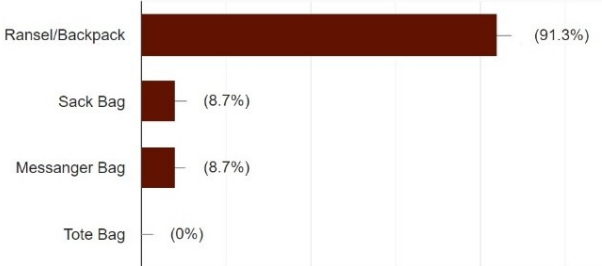

Gambar 4. Jenis Tas yang digunakan responden.

Dari data di atas dapat disimpulkan bahwa tas yang paling banyak digunakan oleh responden adalah jenis tas ransel atau backpack. Karena dari beberapa jenis tas yang ada di pasaran, tas ransel dinilai memiliki kapasitas yang paling relevan untuk membawa barang bawaan ke sekolah setiap hari.

6. Barang-barang yang biasa di bawa ke sekolah 


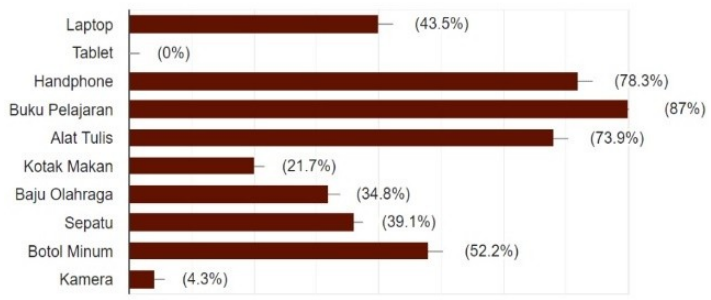

Gambar 5. Barang yang biasa dibawa responden ke sekolah.

7. Aktivitas keseharian

Berikut adalah data seputar aktivitas yang biasa dilakukan siswa di luar jam sekolah.

Bagaimana mereka berangkat ke sekolah:

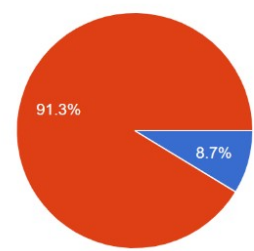

- Sepeda

- Sepeda Motor

Mobil

- Angkutan Umum

$8.7 \%$

(n)

Gambar 6. Transportasi yang digunakan responden.

Aktivitas setelah pulang sekolah:

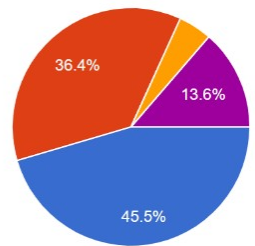

$$
\begin{aligned}
& \text { Kegiatan Ekstrakurikuler } \\
& \text { Bimbingan Belajar } \\
& \text { Organisasi } \\
& \text { Kelas Kursus } \\
& \text { Komunitas }
\end{aligned}
$$

Gambar 7. Aktivitas setelah sekolah oleh responden.

Pertanyaan selanjutnya adalah pertanyaan seputar aktivitas rutin mereka dari hari Senin hingga Sabtu:

Tabel 3.

Model persekolahan dari responden.

\begin{tabular}{lll}
\hline \hline No & Fullday School? & Respon \\
\hline 1. & Ya & $10 \%$ \\
2. & Tidak & $90 \%$ \\
\hline \hline
\end{tabular}

Jawaban dari pertanyaan di atas menunjukkan bahwa dalam seminggu, siswa-siswa ini bersekolah selama 6 hari, yakni hari Senin hingga Sabtu. Dan dalam satu hari, seorang siswa menghabiskan waktu 6-7 jam dari pukul $07.00-$ 13.00. Sementara $10 \%$ responden yang sekolahnya menerapkan sistem Full Day School, dalam satu hari menghabiskan waktu 8 jam dari pukul 07.00-15.00 untuk kegiatan sekolah.

Jika dilihat dari data sebelumnya, mengenai aktivitas setelah pulang sekolah, artinya pada hari-hari tertentu mereka menempuh waktu hampir 9 jam dalam sehari dikarenakan kegiatan Ekstrakurikuler, Bimbingan Belajar, atau kegiatan lain. Dengan demikian dapat disimpulkan data ini sangat penting dalam menentukan kebutuhan desain tas sekolah.

Setelah pertanyaan seputar karakter dan aktivitas keseharian siswa, dilanjutkan dengan mengajukan pertanyaan seputar konsep desain. Pertanyaan ini meliputi penilaian responden tentang konsep desain tas sekolah.

Berikut adalah hasil yang didapatkan dari pertanyaanpertanyaan seputar konsep desain:

8. Bagaimana pendapatmu jika tas sekolah didesain dengan sistem modular?

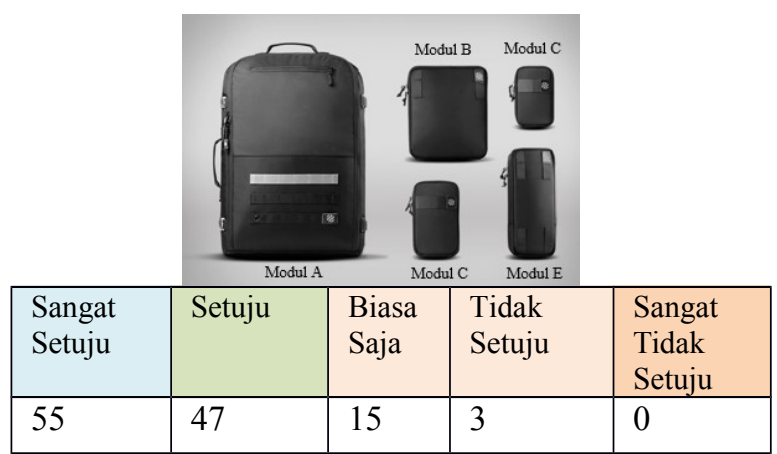

Gambar 8. Respon responden.

Berdasarkan pengamatan di lapangan, didapat banyak siswa SMA yang membawa tas tambahan saat ke sekolah. Tas tersebut berupa tas laptop, totebag, kantong plastik, dan tas lain seperti tas lunchbox. Ditinjau dari data sebelumnya mengenai aktivitas harian siswa, tidak setiap hari tas mereka berisi muatan yang sama. Hal ini terjadi karena jadwal yang berbeda setiap harinya.

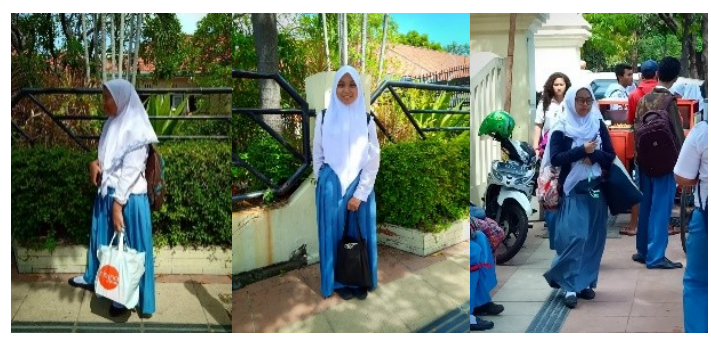

Gambar 9. Siswa membawa tas lebih dari satu ke sekolah. (Sumber: Dokumen Penulis)

Sistem modular yang dimaksud pada pertanyaan di atas adalah membagi 1 unit tas menjadi beberapa modul kompartemen yang disesuaikan dengan muatan yang dibawa, serta dapat dikonfigurasikan sesuai dengan kebutuhan siswa pada hari-hari tertentu.

9. Dari beberapa konsep tas modular di bawah ini, tas mana yang menurut kalian paling cocok diterapkan?
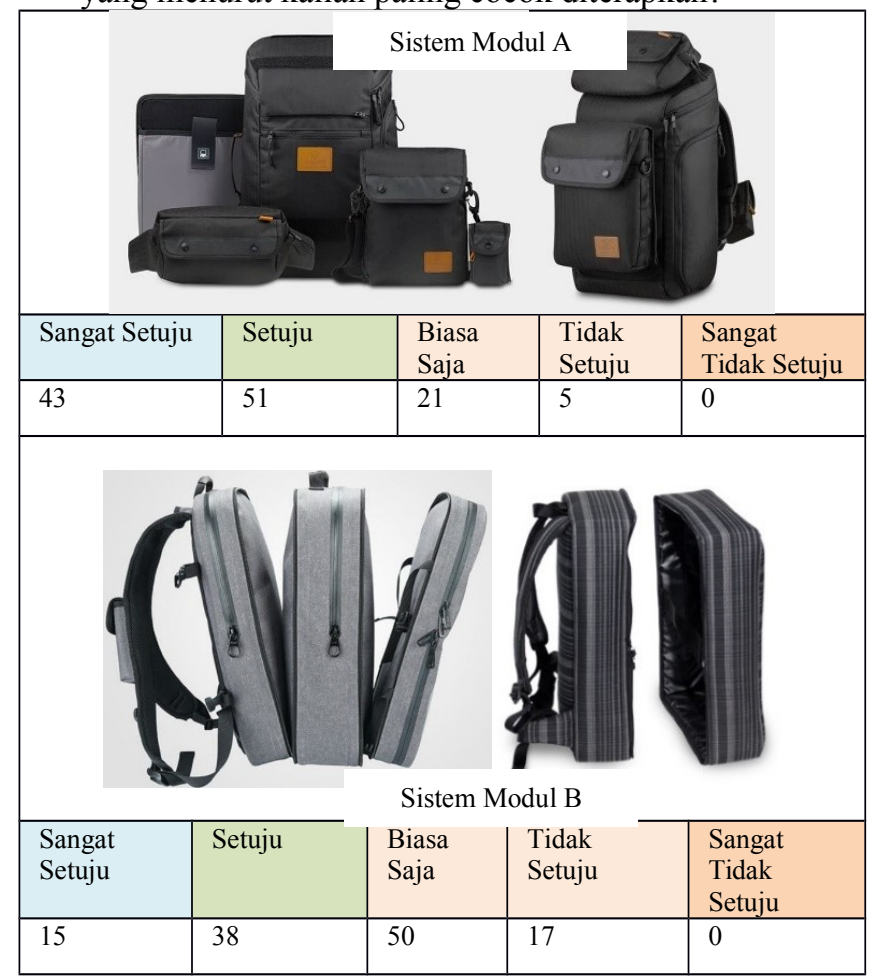

Gambar 10. Konsep tas modular. 
Pada pertanyaan di atas, diperlihatkan beberapa contoh gambar tas dengan konsep modular. Kata modular dapat diartikan sebuah konfigurasi yang berbentuk pengulangan, penambahan, perbesaran, dan kombinasi dari modul-modul yang terurai. Modular merupakan sistem penggabungan dengan cara menyatukan beberapa bentuk yang dapat berfungsi sesuai kebutuhannya [11]. Dari hasil kuisioner responden lebih memilih Sistem Modul A (sangat setuju 43 setuju 51) daripada B (sangat setuju 15 setuju 38).

10. Tas sekolah harus mendukung gaya berpenampilan dan karakter anak muda.

\begin{tabular}{|l|l|l|l|l|}
\hline $\begin{array}{l}\text { Sangat } \\
\text { Setuju }\end{array}$ & Setuju & $\begin{array}{l}\text { Biasa } \\
\text { Saja }\end{array}$ & $\begin{array}{l}\text { Tidak } \\
\text { Setuju }\end{array}$ & $\begin{array}{l}\text { Sangat } \\
\text { Tidak } \\
\text { Setuju }\end{array}$ \\
\hline 81 & 34 & 5 & 0 & 0 \\
\hline
\end{tabular}

Gambar 11. Respon terhadap gaya berpenampilan.

Berdasarkan hasil kuisioner di atas, responden sepakat tas sekolah adalah bagian dari pelengkap gaya berpenampilan para siswa. Trend tas dari segi style, warna dan pattern ternyata menjadi pertimbangan seorang siswa dalam memilih tas sekolah. Kemudian pertanyaan dilanjutkan untuk mengetahui trend warna dan corak seperti apakah yang menjadi daya tarik untuk siswa dalam memilih sebuah produk tas sekolah.

11. Apakah beberapa contoh tas di bawah ini sudah merepresentasikan karakter anak muda?

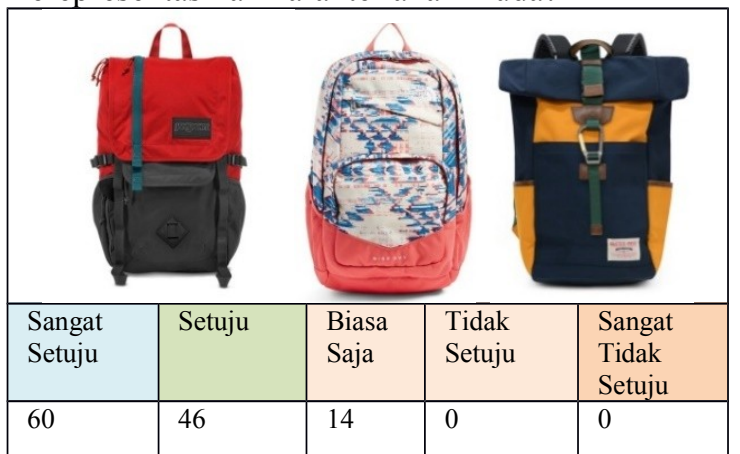

Gambar 12. Respon responden tentang karakteristik tas yang dipakai anak muda.

Dari pendapat mereka tentang karakter warna dan style tas sekolah untuk anak muda, sebagian besar dari mereka sangat setuju dengan beberapa contoh tas yang disajikan (warnawarna cerah dengan pola grafis yang dinamis). Warna merupakan salah satu faktor estetik yang cukup penting untuk sebuah produk. Meskipun bukan faktor utama, namun estetikalah yang mempengaruhi kesan pertama konsumen [12].

Pertanyaan yang tak kalah penting adalah mengenai material dan aksesoris pada tas sekolah. Mengingat tas sekolah adalah produk yang digunakan oleh siswa dengan intensitas waktu yang cukup lama dan harus dapat melindungi barang bawaan mereka dari segala cuaca.

12. Dari beberapa jenis bahan tas di bawah ini, manakah

bahan yang paling cocok diterapkan? (Gambar 13)

Dari penilaian responden terhadap beberapa contoh tas pada pertanyaan di atas, pilihan terbanyak mengacu pada tas dengan bahan nylon atau polyester. Bahan ini terbuat dari serat sintetis yang lebih tahan air (water resistant) dibanding kedua bahan sebelumnya yakni kulit dan kanvas. Tas sekolah harus dapat melindungi barang bawaan dari berbagai cuaca, mengingat aktivitas siswa yang cukup padat baik di dalam maupun di luar ruangan. Selain itu, tas juga harus dapat melindungi barang bawaan dari kerusakan, baik gesekan atau benturan.

\section{KESIMPULAN}

Pada jejang Sekolah Menengah Atas, tas sekolah merupakan sebuah item yang wajib dimiliki oleh seorang siswa untuk membawa barang-barang bawaan mereka ke sekolah. Spesifikasi dan kapasitas dari tas menjadi sangat penting mengingat barang bawaan mereka yang cukup banyak.

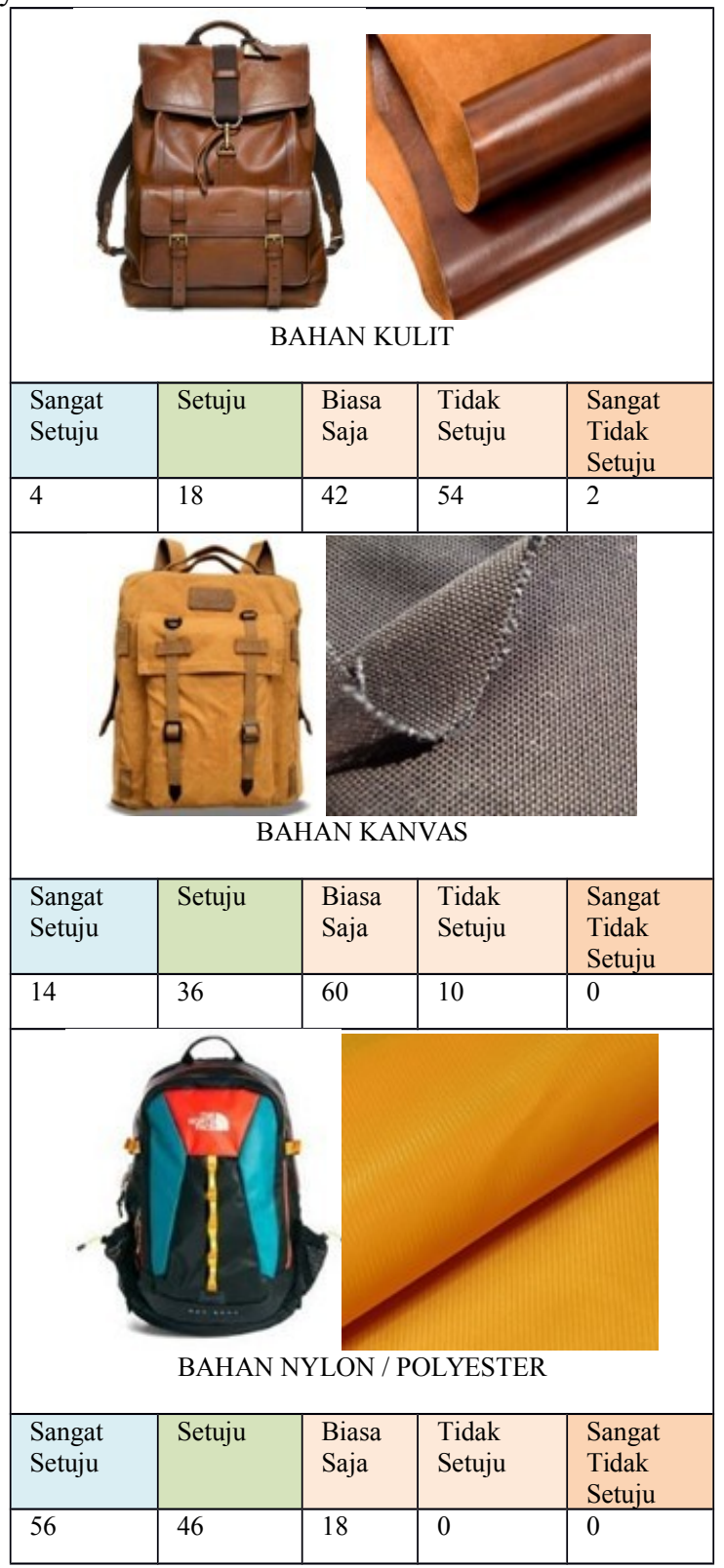

Gambar 13. Hasil penilaian responden.

Untuk itu desain tas sebaiknya sesuai dengan kebutuhan siswa SMA, meliputi jenis tas, bentuk, fitur dan pemilihan bahan dalam rangka mengikuti aktivitas sehari-hari mereka.

Tabel 4 adalah hasil analisis kebutuhan yang telah disusun dalam sebuah Tabel kebutuhan berdasarkan data yang diperoleh.

Dari data hasil riset konsumen dapat di simpulkan bahwa seorang siswa membawa barang yang berbeda-beda tiap hari dalam seminggu. Secara tidak langsung mereka membutuhkan tas yang mampu menyesuaikan keadaan 
tersebut, sebuah tas yang mampu mengorganisir barang bawaan mereka baik ketika jam normal maupun ketika ada jadwal tambahan.

Sehingga dapat disimpulkan, kebutuhan tas yang sesuai untuk siswa sekolah menengah berdasarkan hasil riset adalah sebagai berikut:

Tabel 4.

Psikografi Konsumen

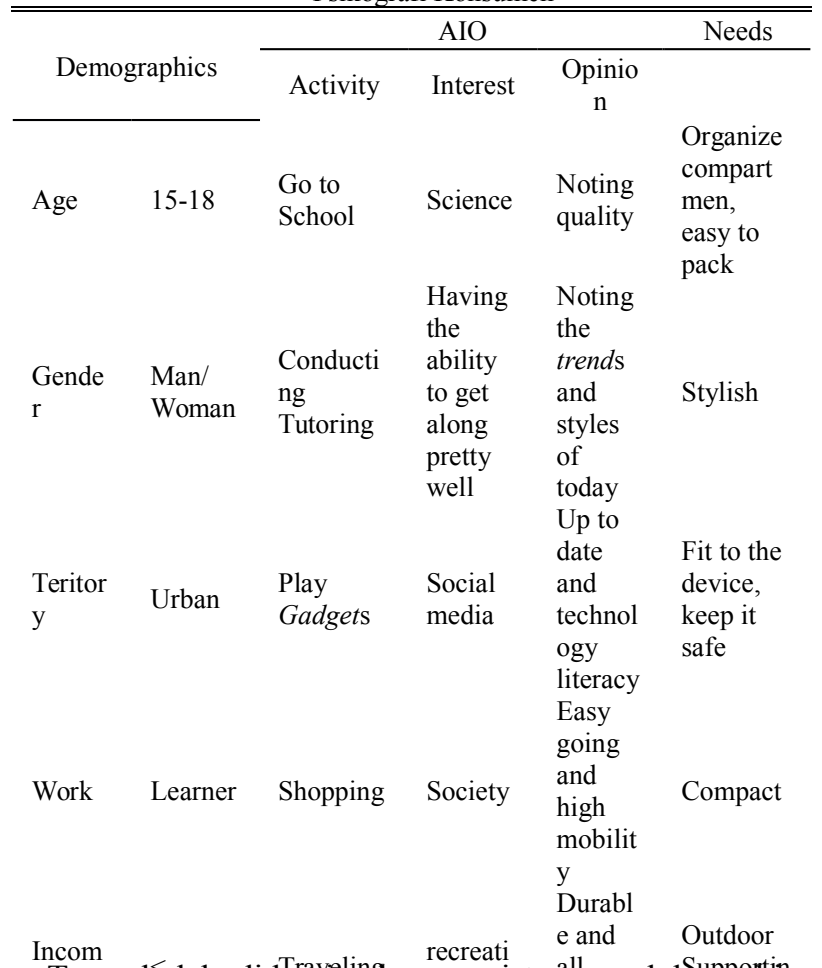

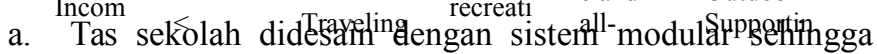
mampu mengorganisir setiap keperluan sekolah dengan kompartemen yang menyesuaikan kegiatan yang dilakukan setiap hari. Modul-modul tas tersebut disesuaikan dengan barang-barang yang selalu mereka bawa berdasarkan data tentang barang bawaan siswa dan aktivitasnya.

b. Membagi tas dalam beberapa kompartemen modul yang terpisah dan dapat dikonfigurasikan sesuai dengan kebutuhan barang yang akan dibawa. Konfigurasi disusun menggunakan sistem join antar modul yang mengacu pada jenis barang bawaan siswa. c. Tas sekolah didesain sesuai dengan trend, gaya dan karakteristik warna anak muda. Selain sebagai produk yang fungsional, tas sekolah juga digunakan sebagai penunjang gaya berpenampilan anak muda pada umumnya. Karakter estetika dan warna mengacu pada data mengenai penilaian responden seputar estetika dan warna pada tas sekolah.

d. Tas sekolah harus dapat menjaga barang bawaan dari berbagai cuaca, dengan memperhatikan pemilihan material serta fitur yang sesuai. Berdasarkan data yang diperoleh, bahan tas yang digunakan adalah bahan sintetis sejenis nylon atau polyester dengan karakter yang kuat dan memiliki serat yang cukup baik.

\section{DAFTAR PUSTAKA}

[1] S. Kollerud and M. Kvidaland, "Influences of product design on consumer behavior," 2018

[2] A. Stankevich, "Explaining the consumer decision-making process: Critical Literature Review, the Faculty of Behavioural," Netherlands, 2017.

[3] N. P. Anjarsari, "Riset pasar produk piemirsa (Pie Intip Rasarasa)," J. Tek. Ind., 2017.

[4] A. Alexander, D. Wahjudi, and J. Budiman, "Analisis kebutuhan konsumen dan rekomendasi perancangan perumahan dengan luas bangunan 36-70M²," J. Magister Tek. Sipil, 2015.

[5] H. Soekkha, Aviation safety: human factors, system engineering, flight operations, economics strategies, management. Tokyo: Utrecht, the Netherlands, 1997.

[6] T. S. Legiran and M. R. Pratiwi, "Hubungan antara penggunaan tas sekolah dan keluhan muskuloskeletal pada siswa sekolah dasar," J. Pendidik. Dr., 2018.

[7] A. Patil and S. Mathad, "Design and analysis of backpack structure for school children using fea tool," Journal. B.V.B. Coll. Eng., 2018.

[8] B. Tristiyono, "Desain interior kereta api kelas eksekutif generasi terbaru dengan konsep modular," J. IDEA, 2009.

[9] S. Arifin, "Konsep dasar, tujuan, dan ruang lingkup riset konsumen," www.academia.edu. [Online]. Available: www.academia.edu/Riset Konsumen.

[10] K. Adams, Non-functional requirements in systems analysis and design, topics in safety, risk, reliability and quality. Switzerland Springer International Publishing, 2015.

[11] B. Tristiyono, "Modular concept as trigger new product development case at panel interior of train executive class new generation PT.INKA," its.ac.id, 2011. [Online]. Available: http://personal.its.ac.id/files/pub/4719-BambangTE-2. aptecs 2011-modular concept.pdf.

[12] C. Lituhayu, "Pengaruh warna terhadap psikologi pengguna dalam perancangan fasilitas bedah plastik estetik," itb.ac.id. [Online]. Available: http://jurnals1.fsrd.itb.ac.id/index.php/interior/article/view /25/23. 